\title{
Women and 'the Other Room': Emancipating the Society
}

\author{
Etuwe Ruth Epochi-Olise and Mitti Peter Monye
}

\begin{abstract}
Pan-Africanism is an ideology which emphasizes the brotherhood of the black people wherever they are. Its advancement is everyone's affair whether male or female, within Africa and the Diaspora. Pan-Africanism has moved from the level of black liberation and struggle for political power to social, economic, and political emancipation, which has positively ignited the desire in some African women to actualize "self' and contribute to nation building in spite of being confined to "the other room". The premise of the "other room" was ignited by a statement made by the President of Nigeria, President Muhammadu Buhari that: "... but she [his wife] belongs to my kitchen and my living room and the other room". This paper sets out to lay bare the principles and relationship of Pan-Africanism and Womanism. The paper further advocates that women in spite of being suppressed are bursting forth; challenging patriarchal roles, which most times impede their growth and development in the society. The paper concludes that women's emancipation, gender equality and women's empowerment are at the heart of the question of humanity itself and are thus universal in character and asserting their place in the global community is fundamental.
\end{abstract}

Keywords: Pan-Africanism, womanism, emancipation, gender equality, 'The Other Room'.

\section{Résumé}

Le panafricanisme est une idéologie qui met l'accent sur la fraternité du peuple noir où qu'il se trouve. La promotion du panafricanisme est l'affaire de tous, hommes et femmes, en Afrique et dans la Diaspora. Le panafricanisme est passé de la libération des Noirs et de la lutte pour le pouvoir politique à l'émancipation sociale, économique et politique suscitant chez certaines femmes africaines le désir d'actualiser « le soi 》 et de contribuer à la construction de la nation, bien qu'elles soient confinées dans 《l'autre pièce 》. La prémisse de 《l'autre pièce 》a été enflammée par une déclaration du président du Nigeria, le président Muhammadu Buhari, dont l'extrait suivant : 《 ... mais elle [sa femme] appartient à ma cuisine, à mon salon et à l'autre pièce $\gg$. Cet article a pour but d'exposer les principes et les relations du panafricanisme et du féminisme. L'article défend également l'idée que les femmes, bien que réprimées, sont en train d'exploser et de défier les rôles patriarcaux qui, la plupart du temps, entravent leur croissance et leur développement dans la société. L'article conclut que l'émancipation des femmes, l'égalité des sexes et l'autonomisation des femmes sont au cœur de la question de l'humanité elle-même ; ainsi, elles ont un caractère universel et il est fondamental d'affirmer leur place dans la communauté mondiale.

Mots-clés: Panafricanisme, féminisme, émancipation, égalité des sexes, “l'autre pièce”.

https://dx.doi.org/10.4314/contjas.v8i1.5

Epochi-Olise Etuwe Ruth (epochiruth@yahoo.com) earned her B.A. [Hons.], M.A. and PhD at the University of Ibadan. A director, actor and theatre manager, she is currently a Senior Lecturer of Drama and Theatre at the Alex Ekwueme Federal University, Ndufu-Alike (AE-FUNAI), Ebonyi State, Nigeria. Epochi-Olise has directed over fifteen plays and her research and teaching interests cuts across Dramatic Literature, Theatre Studies (Costume and Make-up Designs, Acting and Speech Arts, Play Directing, Theatre Workshop), Carnival Arts, Performance Studies (African Performance Tradition), Gender Studies and Children's Theatre. Epochi-Olise is a Fellow of the Ife Institute of Advanced Studies (IIAS). She has published academic papers and books in her areas of interest. She has reviewed articles in Nigerian Theatre Journal, Journal of the Society of Nigeria Theatre Artists, Journal of Educational Research and Review (JERR) among others, and co-edited Nnu Ejije (The Salt of Performance), A Journal of Theatre and Media Studies.

Monye Mitti Peter (mittimitti25@yahoo.com) is a Chief Lecturer affiliated with the College of Education, Agbor, Delta State, Nigeria. His research interests are African Dance and film/radio studies. He holds a Master of Arts in Theatre Arts from the University of Ibadan, Nigeria. 


\section{Introduction}

At this stage of the story, it is important to note that long before the idea of Pan-Africanism was formulated in response to Western domination, the history of Africa was interspersed with many acts of resistance, some of which had been organized and led by women (Reddock, 2014). According to Corneliussen, [women] have been fighting against slavery, wars and victimization through centuries in a battle that is far from ended (2012: 5-6), African women were always portrayed as subordinate - submissive, subdued, passive and subjugated (Corneliussen, 2012; Oyeronke, 1995). There was therefore no question of raising their profile by giving them a major role in the written history of Africa (Llyod, 1989; Campbell, 1994). In coming together through their organizations, African women sought to build a forum for solidarity and mobilization that would lend greater weight to their voice, not only in their own countries, but also on the international scene (Mohanty, 2003; Corneliussen, 2012). Through those international platforms they met other activists from colonized countries and developed countries and learnt about the strategies adopted in various parts of the world to secure women's empowerment. Women of recent generations have built on the lessons learnt from Pan-Africanism to take part in the anti-colonial, anti-racist struggle and stake their claims for a better status in society (Ampofo, et al 2008). Through their associations, they have joined forces beyond the borders of their respective countries to influence policies for the development of independent Africa and to voice their hopes for their society to be more open to the emancipation and empowerment of women (Tsikata, 2001; Wing, 2002). Although the situation is still uneven from one country to another, African women's mobilization and initiatives have given them international standing and have raised their profile in many national and international decision-making bodies.

We must make empowerment a certainty, so that women can become the protagonist of their own emancipation. All we need do is to encourage this process as part of our endeavors to leave behind the outdated customs, sexist intolerance, and confined roles of women as established patriarchy. When the African women's movement wakes up to the extent that their oppression is a key component in the multi-national exploitation of Africa's wealth, then we shall have the key conceptual framework on which to base a Pan-African movement for the liberation of women.

Pan-Africanism is an ideology which emphasizes the kinship of black people, wherever they are, whether in Africa, America, Asia, or Europe. It is an expression of the desire for African unity as well as the unity of all people whose ancestry is Africa (Francis, 2006: 5-6). Pan-Africanism has moved to another level in the struggle for political power to complete social, economic and political emancipation (Adogamhe, 2008). Women in Africa and the Diaspora played critical roles in the advancement of Pan-Africanism through their contributions to all forms of black liberation struggles. These women's role in forms of resistance against slavery, colonization and patriarchal domination has been ongoing for an extended period. Most of their activism was linked to nationalist struggles for independence, all in a bid to defend themselves and their nations. African women's movement started from different historical perspectives, contexts, priorities and having different affiliations to political parties and government. Some of these women have always been brave, refusing to accept the status quo and have challenged the position imposed upon them by the patriarchal order.

Women stretching from East African to the West, North and South made their mark in terms of these resistances; women like Efunsetan Aniwura of Ibadan, Adunni Oluwole and Madam Efunroye Tinubu of Lagos, Inkpi of Igala, Funmilayo Ransome-Kuti, Margaret Ekpo, Charlotte Obasa, Oyinkan Abayomi and Queen Amina of Zazzau among others, taught others the means of surviving in this world as a woman (Awe, 2000). Even in their vulnerable state to the harsh realities of life, these women were sharp, tough and empowered in ways that few men were. In 1914 the year Nigeria was formed, women staged a major protest, which was referred to as the "Ogidi Palaver", against both indigenous and British men who had jointly side-lined them in decision-making. While in 1925, the "Nwaobiala Movement" referred to as the Aba riot, saw women forcefully rejecting colonial values culminating in 1929 into what is known as the "Women's War", where 10,000 women participated and dozens lost their lives fighting back against a drop in female authority. In Mauritania, a formidable black woman named Dahia al-Kashina became the leader of the African forces around 690 and forced Arab invaders into a temporary retreat. Queen Nzingha, on the other hand, presided over Angola and Zaire as a result of her military expertise. She was a formidable opponent who was determined to destroy the slave trade by the Portuguese and their army who were hell-bent on enslaving Africans. But with her expertise, the Portuguese were held off for over 40 years. Mbuya Nehanda, Chaminuka and Kaguvi from Zimbabwe played a key role in the mobilization of resistance to colonial rule in Zimbabwe. They inspired the first uprising against white invaders, who started imposing taxes on black Africans, forcing them into labour and taking their land. Yaa Asantewa of Ghana was a leader and one of the powerful warriors of her people. She challenged, rebuked and led a courageous resistance against the British. While Queen Nanny of the Maroons was the spiritual, cultural and military leader of the Windward Maroons, who also put up a fierce resistance against the British army as she tried to preserve her African culture and identity. In Kenya, Field Marshall Muthoni Kirima was one of the Mau Mau freedom fighters, who chose to fight for land and freedom. While in South Africa, women also played important roles in the struggle against the apartheid regime.

These women were opposed to laws governing black Africans and also delivered literacy, nutrition and health classes. 
Winnie Madikizela Mandela was one of the major arrowheads in this struggle, hence she was known as Mother of the Nation. Then the Rosa Park protest in the United States of America (Falola, 1991; Sofola, 1994; Gabriel, 2007).

Looking at African women from the beginning of time, we can convincingly say that they have played a very significant part in the founding of communities, in defending humankind, their civilization and culture as well as fighting for their emancipation and self determination. These events have positively ignited the desires in some African women in their efforts to self-actualize and contribute to nation building in spite of being confined to "the other room".

This paper, therefore, sets out to lay bare the principles of Pan-Africanism and Womanism. The paper shows that Pan-Africanist ideals are closely related to Womanism, whose ideologies are essentially the same: dignity, fundamental human rights of people, especially the black women who have suffered marginalization, oppression, and deprivation among others. The paper advocates that women in spite of being tied down with the monotony of life as wives, mothers, punching bags, sex objects, etc are bursting forth, challenging patriarchal roles, which most times impede the growth and development of women in the society. This is why Barbara Christian avers that "the African woman is not content in being a victim, she opts to be an actor in the post-colonial world" (1985: 147). In re-creating and re-writing women's role in the society, women seek to change their inactive roles in a male dominated society. They can be viewed as nationalists and Pan-Africanists in their struggle to actualize self. Without the participation and emancipation of African women, the value of investing on women cannot translate directly into human and social development in the society. The paper concludes that women's emancipation is at the heart of the question of humanity itself and it is therefore universal in character and asserting its place in the global community.

\section{Pan-Africanism as an ideology in relation to womanism}

Pan-Africanism is an ideology and movement that emphasizes the brotherhood of people of Negro blood whether in Africa or the New World (Simon \& Obeten, 2013), which calls for, defends and cultivates unity, human equality, human rights, global solidarity and cooperation among Africans worldwide, in order to be liberated from racist oppression, discrimination, neo-colonial and imperialist domination as well as establishing independence for African states (Campbell, 1994; Mudimbe, 1994; Bogues, 2011; Reddock, 2014: 59). According to Colin Legum, PanAfricanism is "the expression of the desire for African unity as well as the unity of all people whose ancestors originally came from Africa" (528). Pan-Africanism requires and encourages a sense of cooperation and unity of all Africans, in spite of social, economic, religious and political disparities on the basis that Africans the world over have a common history and destiny (Adi \& Sherwood, 2003). Nnamdi Azikiwe in his The Future of Pan-Africanism says:

When we speak of Pan-Africanism, what do we exactly mean? ...To some people, PanAfricanism denotes the search for an African personality. To others, it implies negritude. Whilst to many it connotes a situation which finds the whole continent of Africa free from the shackles of foreign domination with its leaders free to plan for the orderly progress and welfare of its inhabitants... unless we accept a broad definition of terms, there can be no worthy future of Pan-Africanism. That being the case, I would like to speak of the people of Africa in general terms to include all the races inhabiting that continent and embracing all the linguistic and cultural groups who are domiciled therein... It would be useless to define "Pan-Africanism" exclusively in racial or linguistic terms, since the obvious solution would be parochial (1962: 10-11).

In examining the statement of Nnamdi Azikiwe above, it is pertinent to say that Pan Africanism is a lived experience and as such should centralize the expressions of new experiences in each epoch as it affects Africans. Pan-Africanism, as an inimitable cultural and spiritual movement for the promotion of negritude became first used among the black Americans and West Indians in the 19th century (Lemelle, 1992; Murithi, 2007). It was the struggle to end slavery and the slave trade, though was born in the New World but with its ancestral land in Africa. The black people worldwide became conscious of the similar problems they were facing and they could only effectively tackle it through unity. This is because the descendants of the Negro slaves, through their dislodgment from their cultural heritage and forced conformity to alien culture saw themselves as orphans of Africa and aliens in the world of white domination and exploitation (Legum, 1965). Pan-Africanism assumed a political dimension in the 20th century, with several adherents, within and outside Africa with the likes of Jomo Kenyatta of Kenya, Kenneth Kaunda of Zambia, Kwame Nkrumah of Ghana and Julius Nyerere, among others, who are passionate Pan-Africanists. They believe that Pan-Africanism is an idea based on the belief that to achieve collective selfreliance, unity is vital if people of African descent are to achieve economic, social, and political progress as well as to safeguard their common interests (Murithi, 2007: 2).

However, the concept finally took shape in Africa through the dogged pursuit of Kwame Nkrumah for a strong movement of African unity (Nwoko, 2006). He was the first African leader to attract international fame in this regard and represents for the black world a symbol of unity. Nkrumah was described as an advocate of PanAfricanism who played a vital role in the establishment of our Continental Organization, Organization for African Unity, and the liberation of the Continent (Quist-Adade, 2010) which was part of his brain child and achievement in 
Africa. Some scholars still affirm that former President Nkrumah was not only a visionary leader, but a leading voice that vigorously campaigned for the political unification of Africa (Saaka, 1994; Agyeman, 1975; Olaosebikan, 2011; Okhonmina, 2009; Adogamhe, 2008; Biney, 2011; 2008). To them, Nkrumah understood the importance of shared strength in political unity and considered the idea as the most definite solution to the socio-economic and political problems that faced the newly independent states across Africa. According to Mazrui:

Nkrumah's greatest bequest to Africa was the agenda of continental unification. No one else has made the case for continental integration more forcefully, or with greater sense of drama than Nkrumah. Although most African leaders regard the whole idea of a United States of Africa as wholly unattainable in the foreseeable future, Nkrumah even after death has kept the debate alive through his books and through the continuing influence of his ideas (2004: 22).

Kwame Nkrumah further states that an African Common Government will promote the unity of Africa and Africans as well as help in achieving a number of social, economic and political objectives.

The principal goal of Pan-Africanism was to scrutinize the situation the African race is faced with in every corner of the globe, to seriously condemn the unwarranted disdain and abhorrent treatment which they encounter daily. The foremost impact of Pan-Africanism on the African psyche is the consciousness of self dignity and the need to be adamant on the consciousness of individual dignity over collective suppression (Ogba \& Okpanachi, 2014). Nkrumah's aims were for the projection of the African personality, overcoming the destructive forces of neocolonialism, enhancing the security and cohesion of African states, transforming the political map of Africa, putting an end to European exploitation of Africa, overcoming the problem of cultural divisions in Africa, effective exploitation and $\mathrm{co}^{-}$ordination of Africa's resources for sustainable development, and promoting world peace and security (Nkrumah, 1963; Kanu, 2013).

Pan-Africanism as a philosophy represents the whole of the historical, cultural, spiritual, artistic, scientific and philosophical heritage of Africans in all ages. The ideology asserts that the fates of all African people, both on the continent and in the Diaspora, are entwined with and stuck in the principles of political equality, subjugating narrow-minded interest to the greater common good, collaboration with like-minded institutions and strategic integration. All these testify to a belief that all peoples of African descent "share not merely a common history, but a common destiny" (Echo, 2013: 1).

Pan-Africanism as an ethical system promotes values that are the product of ancient African civilization and the struggles against slavery, racism, colonialism, and neo-colonialism (Shema-Rutagengwa, 2009). Africans should be encouraged to celebrate their national pride as well as their collective pride; they should consciously identify, constantly promote and build on what unites them as Africans, without overlooking disparities, but rather unearth constructive ways to express our differences; and should deliberately reinforce internal machineries for conflict management and resolution as a means of reducing all circumstances that distracts them from major objective of achieving unity and solidarity in Africa and among Africans.

As a movement, Pan-Africanism significantly emphasizes that solidarity and all-African alliance will empower self reliance, especially allowing Africa's potentials to prosper, empower and fulfill the destiny of all African peoples globally, irrespective of their sex (Alexander, 2003). Because women have been consistently erased from the history of Pan-Africanism, it is important to assert from the beginning that there has been a presence of active women from the very start of Pan-Africanism and women who are Pan-Africanists practiced the art of navigating a variety of complex positions around race, gender, class, national origin and culture within the larger goal of the liberation of African peoples internationally. Without these women, Amy Ashwood Garvey, Shirley DuBois, Florence Matomela, Mabel Dove, Ardua Ankrah, Fathia Nkrumah, and Aya Chebbi, among others, the history of Pan- Africanism cannot be said to be complete (Azikiwe, 2016; Enero, 2018).

Feminism is a discourse that involves diverse movements, theories and philosophies which are concerned with the issue of gender difference. From the onset, feminism has its origin in the struggle for women's rights; women became conscious of their oppressive state and fashioned ways to remedy this oppression and helping them to have a voice (Spelman, 1988: 65; Rublin, 2007; Tao, 2018). It particularly focuses on women's experiences and lay emphasis on the various types of oppression which the woman is subjected to in the society (HudsonWeems, 1993; Hooks, 1998; Sotunsa, 2008; Mekgwe, 2008; Mama, 2016). According to Barrow and Millburn, feminism is "a label for a commitment or movement to achieve equality for women" (1990: 128). Over the years, it has seen and given birth to many new meanings, shades as well as nomenclature - from Western feminism of Mary Wollstonecraft, Sara M Grimke, Simone de Beauvoir, Helene Cixous, Virginia Woolf to Black feminism of Catherine Acholonu's motherism, Omolara Ogundipe-Leslie's stiwanism, Alice Walker's womanism, Hudson-Weems'Africana womanism, and Chikwenye Okonjo's black womanism, among others. Feminism started in Europe and America in the 17th century when women in the aristocratic class began to demand for improved rights and opportunities (Clifford, 2001; Simon \& Obeten, 2013). Back in Nigeria, Feminism took roots in Nigeria in the 1980s through the efforts of NGOs like Women in Nigeria (WIN) and some female academics like Bolanle Awe, Molara OgundipeLeslie, Helen Chukwuma, and Theodora Ezeigbo, among others (Madunagu, 2008; Salami, 2018; Adagbada, 2018). Helen Chukwuma adds that feminism means: 
a rejection of inferiority and a striving for recognition. It seek to give the women a sense of self as a worthy, effectual and contributing human being. Feminism is a reaction to such stereotypes of women which deny them a positive identity (ix).

From the above statement, feminism is not about finding equality with men, it is trying to build a harmonious society, where a woman seeks her happiness and self-accomplishment outside prescribed gendered roles (Singh, 1997: 23; Adagbada, 2015).

From the look of things, feminism has found broad reception in Africa, especially among exploited and long maltreated African women and their sympathizers. It, therefore, advocates equality for women and campaigns for women's rights and interests (Tuttle, 1986; Beasley, 1999: 27-28; Gamble, 2001). Most importantly women's organizations should intentionally link Pan-Africanism as an ideology and philosophy to feminism and African feminist principles and values because unity and solidarity among African people should be based on human and gender equality.

The terminologies may be new, but their ideas are not. In fact, many black women at various points in history had a clear understanding that race issues and women's issues were inextricably linked, so should not be separated from each other (Strong-Leek, 2005). There is an even more cautious kind of feminism called womanism (Walter, 1983; Ogunyemi, 1985; Hudson-Weems, 1993; Kolawole, 1997), which denies being a product of feminism but endeavors to review problems facing gender dynamics and patriarchal oppression in various cultures. The supposed disparity with other form of feminism is that it tries to avoid recklessness and egotistic opinions that some cultures within the diverse body of African feminism houses. Womanism, hence, gives significance to the collective female experience and the well-being, survival and totality of the entire people. It became an answer and a tool for black women to fight and challenge the policies which marginalized them, without turning against men as well as to foster bonds between both sexes (Bryant-Davis \& Comas-Diaz, 2016: 6; Kobo, 2016). Its major aim is to preserve a human essence through the complementary roles both sexes play, thus the family system is the crux. For the purpose of this paper, the researcher shall be looking at womanism as a variant of feminism as proposed by African women to drive home their desire to be emancipated.

Womanism is rooted in Black culture in spite of the diverse nature of African cultures. It basically defines itself as African women, jointly working with African men to develop scheme to appraise the oppression of colonialism and neo-colonisation (Brown-Douglas, 1993; Phillips, 2006: xx; Harrell, et al 2014: 75). However, it accounts for the centrality of family, community, marriage and motherhood as positive experiences for African women, but is devoid of unnecessary aggressiveness. Alice Walker defines a womanist as:

A black feminist or feminist of color... A woman who loves other women, sexually and / or non-sexually. Appreciates and prefers women's culture, women's emotional flexibility (values tears as a natural counterbalance of laughter), and women's strength. Sometimes loves individual men, sexually and/or non-sexually committed to survival and wholeness of entire people, male and female. Not a separatist, except periodically for health. Traditionally universalist... loves music. Loves dance. Loves the moon. Loves the spirit. Loves struggle. Loves the folk. Loves herself. Regardless; womanist is to feminist as purple is to lavender (1983: $x i-x i i)$.

Walker says that feminism and womanism have certain similar features but are undisputedly different. She goes on to reveal that women in one way or the other become linked to patriarchy when they support the power games; try to dominate over others by subjugating them which finally lead to oppressions like racism, sexism, classism, etc. The resolution lies in moving away from dominating conduct and accommodating a liberal opportunity for interaction among both sexes.

On the other hand, Hudson Weems says Africana womanism is:

an ideology created and designed for all women of African descent. It is for grounded in African culture, and therefore, it necessarily focuses on the unique experiences, struggles, need and desires of African women. It critically addresses the dynamics ofthe conflict between mainstream feminist, the black feminist, the African feminist and the Africana womanist ( 1994: 24)

Hudson-Weems precedence in Africana womanism is that Africana people must abolish racist influences in their lives with the understanding that they can neither afford nor tolerate any form of female subjugation. To her, therefore, Africana men and women should be partners. However, the primary aim of Africana women is to fashion their own standards for evaluating their realities, both in thought and in action. Okonjo-Ogunyemi defines her concept of womanism even more explicitly as a philosophy that:

celebrates black roots [and] the ideals of black life, while giving a balanced presentation of black womandom [and] concerns itself as much with the black sexual power tussle as with the world power structure that subjugates blacks (1983). 
She notes the need to focus on ethics of survival. She also highlights the complexity of sexual and gendered relations by arguing that matrilineal and polygynous societies in Africa are dynamic bases for the womanist.

Both Alice Walker and Chikwenye Okonjo-Ogunyemi have defined womanism as a consciousness that incorporates racial, cultural, sexual, national, economic, and political considerations. As Okonjo-Ogunyemi explains, black womanism is a philosophy that concerns itself both with sexual equality in the black community and with the world power structure that subjugates both blacks and women. In the same vein. Aidoo believes that the position of African women is interwoven with the liberation and development of the continent. She believes in a movement that would seek justice not only for African women but for all African people, suggesting an all-inclusive movement that could integrate all people into the construction of the continent. For her, the focus should be on women's strength, determination and capacity to survive in spite of the oppressive socio-cultural conditions of their society because there is no possibility of African development if women do not take part in the project (Aidoo, 1984; 1990; 1993; 1998; Azodo, 2007). In her own words, Aidoo says:

my understanding of Womanism is like feminism. But, because of us being African and black, because of our particular position in history, Womanists believe that special component makes it a little difficult for us to say we are feminists. Womanism adds the added understanding of our position in history to the discourse. You know that we can be feminists. But, you know, on the other hand, we bring more to the discourse, which makes us Womanists. But.. for me that's also problematic, because it is essentializing our situation, which brings its own limitations. I think it is a very complex issue (Azodo, 1999).

However, womanism, like Pan-Africanism advocates the recognition of people's fundamental integrity as well as human rights and is grounded in notions of possibility, hope, and change that enhance optimal living that transcends from survival to thriving (Westfield, 2007). Since Pan-Africanism advocates and anchors on unity and the recognition of people's (blacks) fundamental human rights, these tallies with the women's agenda of womanism, which is accommodationist, though some African female writers are radical and at times militant in their approach Lisa Tuttle defines womanism as an ideology that is:

the advocacy of women's rights based on a belief in the equality of the sexes, and in its broadest use, the word refers to everyone whois aware of and seeking to end women's subjugation in any way and for any reason (107).

However, in trying to situate the African women's movement within the Pan-African Movement, it can arguably be understood as a sub-set of the wider Pan-African philosophy of promoting equal rights, not from the vantage point of colonial rule and racism, but rather patriarchy and other forms of structural inequalities found in the society. African women's movement became more structured as the Pan-African movement gained more momentum with the struggles for independence from colonial rule in the 1960s, with the intention of improving their socio-economic status and positioning in society (Esedebe, 1984; Okeke \& Okechukwu, 2011; AU Echo, 2013). In this way, it widens the understanding of the emancipatory potentials of Pan-Africanism and recognizes the shared experiences of the Pan-African public.

Pan-Africanism has contributed greatly to defining what the women's movement will be able to do for African women as it gives them a sense of common identity and they (women movement) operate within their context. Noting the many strides made towards women, Pan-Africanism within the movement for women has encouraged more tangible and practical links between the ideology and the practice (O'Meally, 2013). As for Pan-Africanism's future contribution to the Women's movement, Pan-Africanism must go beyond breaking down national borders to the minutest of women's issues in the society like creating and enhancing policies for women who are excluded from meaningful participation in all spheres of life not just because of representation but to be fully integrated.

\section{Patriarchal supremacy and the subjugation of those in "the other room"}

"In the beginning of our story all significant societies were clearly patriarchal. There was no single exception" (Therborn, 2004: 17). It therefore means that at the dawn of human history, almost every society and every known culture separated roles and functions between the sexes; women were considered in some degree inferior to men.

Patriarchy refers to the web of economic, political, social and religious regulations that enforces the domination of women by men throughout the ages (Jones, 2000: 77). Albeit, the African culture is particularly patriarchal and patrilineal in nature (Khumabo \& Garbus, 27), hence it is anti-woman as they always view women as non-equals. The woman is, therefore, subjected to harrowing situations that is life-threatening and damaging because of her natural and biological composition. Adrienne Rich (1976) says that:

Patriarchy is the power of ideological political system on which men by force, direct pressure or through ritual, religion, law, and language, customs, etiquette, education, and division of labor, determine what part women shall or shall not play, and in which female is everywhere subsumed under the male (57-8). 
Patriarchal beliefs exaggerate genetic dissimilarities between both sexes, and it assumes the natural superiority of male over female; as a system of social construction and practices, which is depicted by power, supremacy, hierarchy and opposition, men shamelessly dominate, oppress and exploit women (Walby, 1990: 20) and uphold their dependence on, and subordination to men in all spheres of life.

Patriarchy has been defined as a gendered power system (Bhasin, 2006: 3). It is a network of social, political and economic relationships through which men dominate and control female labour, reproduction and sexuality as well as define women's status, privileges and rights in a society. In many African societies, traditional patriarchal gender roles dominate society, significantly influencing the way in which both men and women participate in the society. Traditionally, men are viewed as the head of the household, which also means that they withhold all decision-making power (Elias, 2010). Since men are placed in positions of authority and power as well as determine family tasks and responsibilities, many resources and opportunities are automatically given to them. Patriarchy will act as the parasite that brings the Black Consciousness Movement to its knees. The intention of a patriarchal society is to perpetually dominate women, a domination that finds expression in the monopoly and control of the woman's psyche by men against the dependent woman as a result of their financial enslavement, the emergence of unequal development and struggle between both sexes, which are usually resolved in disputes.

Most societies have created gender roles, but these prejudices of gender have caused several problems. That is why gender, as a social construction which had been shaped by patriarchy, projects inequalities that have a large and far-reaching impact on society because its construction is nothing new to most societies (Sultana, 2011: 3). In fact, nearly all societies in the world practice some form of arrangement based on gender roles. Even when society plays an enormous role in the creation of gender roles of its people, which in turn form their identity, each society does not in any way have complete power over the construction as a result of constant change as it is mainly achieved through societal dynamics. "Gender", according to Lippa (2002), refers to all of the socially defined, learned, or constructed accoutrements of sex. The construction of women's identity projects them as second-class citizens, and this empowers men and society to enforce expectations of the ideal woman, thereby promoting the return to domesticity that justified the release of women from the colonial era.

From the period of slavery up till now, black womanhood has always been man's subordinate if not his slave, destroyed, distorted, dismantled and abused with racial, sexual and inhuman practices by the human race, whether as blacks or whites. In the process, the black woman has lost her personality but rather evolved dual perception of herself to withstand the storm of patriarchy in the society. According to Oyewumi, the concept that we know of as "woman," had to have been invented for the advantage of the concept that we know of as "man." She goes on to say that the oppression of the woman is in the meanings assigned to have a woman's body by male oppressors and the oppression of Black people has been linked to the meanings assigned to have a Black body by white oppressors (1997). It therefore means that the two sexes have never partitioned the world up uniformly; even up till now, the woman is greatly constrained in spite of the current changes. Male domination is found in almost all important aspects of life, and is seen as the source of social inequalities and injustice, which affects the life of women. Feminists, therefore, seek to remove all the barriers of inequality for the social, political and economic opportunities for women. It also goes as far as rejecting the notion that a women's worth is decided chiefly by her gender because she is believed to be inferior, subservient and less intelligent than men (Lerner, 1989).

Nevertheless, women have remained invisible in many aspects including recognition of their roles and contributions to the society. Women are forced to believe in and cope with their limitations fabricated by the society controlled by men. Simone de Beauvoir avers in her book, The Second Sex (1949) that, "One was not born a woman; rather, one becomes a woman" (14). This, de Beauvoir, identifies as fundamental to women's oppression. She argues that women have historically been considered deviant and abnormal. While Betty Friedan criticized the idea that women could only find fulfillment through childrearing and homemaking. In her book, The Feminine Mystique (1963), Friedan hypothesizes that women are victims of a false belief system that requires them to find identity and meaning in their lives through their husbands and children

Women often become feminists by becoming conscious of the misrepresentations of themselves (Tong, 1989: 2). From all indications, some feminists have shown interest in opening up the inner world of women so that they can understand that the rigid patriarchal society treats them as subhuman for their own convenience. The society enforces women to live as inferior beings, lower than men in status, and they yield to their destiny. The patriarchal society starts reshaping them after their birth as the ones to serve the male. Women are the "Others" of society who can never really belong to their society, but are simultaneously essential for its survival. Barbara Christian asserts that, "the enslaved African woman became the basis for the definition of our society's Other" (1985: 160). From the quote above, we see that domination always involves attempts to objectify the subordinate group. In the words of Simone de Beauvoir, "society being codified by man, decrees that woman is inferior"(1961: 404). Her argument is based on the fact that because men view women as essentially different from themselves, they are reduced to the status of the second sex and hence subordinate. Men, as the naming subject of society, have over time come to define the female as everything opposite of what he perceives to be the superior traits of the male race. Therefore, the identity assigned to women is that they are the "Other" to men. Carolyn Heggen states that: 
In patriarchy, women and children are defined in relation to men who control the resources and the power. Women and children are the other, the object. Men are the norm, the subject. In a dominance-and-submission social order, there is no true mutual care. Subordinates are to care for the needs of the dominants (1993: 85).

Subaltern means of lower rank, but Spivak has widened its scope and attributed the term to the literature of marginality and suppressed groups of society. Spivak borrows the term "subaltern" from Gramsci, to refer to unrepresented groups of people in the society (Gramsci 55). By "subaltern", Spivak means the oppressed subjects or more generally those "of inferior rank" (283) among a group or the society generally. The subalterns were made to believe that they belonged to an inferior race and so not fit for making any real contribution to the society. The subaltern female is subjugated by patriarchal hegemony and their identity is considered lacking, subject to discrimination and is forced to keep silent. Spivak's subaltern theory is used to critique patriarchal and phallocentric ideology and hence very relevant in most societies, as this view has helped salvage the woman from any form of subjugation and the patriarchal order which does not allow her to speak.

Women are being treated as the "other", as a subsidiary of the man; the psychological reasons behind this is thus to completely subjugate them under patriarchal dominance and utilize their servile existence whenever needed. According to de Beauvoir:

Man can think of himself without woman. She cannot think of herself without man. She is defined and differentiated with reference to man, and not he with reference to her; she is the incidental, the in-essential as opposed to the essential. He is the subject, he is Absolute, She is the Other (26).

The "Other" is defined by its fault, devalued and susceptible to discrimination. The "Other" of man is woman, an "Other" through whom he seeks himself (Beauvior, 1952; Fanon, 1963). The woman is objectified as the "Other" in ways that were both visibly tyrannical and sinister, but they are reduced to "object" because they are seen as incomplete and incidental beings (Lerner, 1986; Hooks, 2004).

Women are being treated as the "Other" since they are subordinated to men. The "Other" always occupies a position outside ordinary life and they are treated as a subsidiary who does not contribute anything to the welfare of the society. There is supremacy of male domination over women in the society. The dominance of patriarchy has been achieved through historical forces.

The psychological reason behind the treatment of women as the "Other" is to subjugate them under the patriarchal dominance and utilize their servile existence whenever needed. Wolfreys quotes Spivak as saying:

\begin{abstract}
In the case of academic feminism the discovery is that to take the privileged male of the white race as a norm for universal humanity is no more than apolitically interested figuration. It is a trope that passes itself off as truth and claims that woman or the racial other is merely a kind of troping of that truth of man - in the sense that they must be understood as unlike (non-identical with) it and yet with reference to it (172).
\end{abstract}

All societies create the "Self" and the "Other" with their own set of groupings. The term "Other" is highly relative and it goes on changing its significance according to the context, since it is based on a hierarchy of civilization. Societies, in general, have always favoured the male. Insofar as woman is considered the "Other", whoever she is and whatever powers she possesses are seen as inessential, she is never regarded as another subject, since she has never had a direct or independent rapport with men especially as she is always under his guardianship (Beasley, 1999: 27). The woman is destined to be subordinated, possessed, and exploited. This historical factor has paved the way for the treatment of women as the "Other". In the "Introduction" to The Second Sex, De Beauvoir speaks about the concept of the "Other" as:

The category of the Other is as primordial as consciousness itself. In the most primitive societies, in the most ancient mythologies, one finds the expression of a duality - that of a Self and the Other. This duality was not originally attached to the division of the sexes, it was not dependent upon any empirical facts... The feminine element was at first no more involved in such pairs as Varuna-Mitra, Uranus-Zeus, Sun-Moon, and Day-Night than it was in the contrasts between God and Evil, lucky and unlucky, right and left, God and Lucifer. Otherness is a fundamental category of human thought (16 - 17).

The society has identified the woman as a person who belongs to the "fairer sex". It is equal to say that a female is perceived by the society from the point of view of sex. Females play a vital role in the reproduction process and still they are labeled as "the Second Sex or the Weaker Sex or the Other". An "Other" as the Self's shadow, which would consolidate the inside that produces an image of the self. Males themselves cannot live in the society, so they consider women as their supporters and treat them as secondary. The gendered subalterns are playing the role of mere shadows to please their men.

Having been exposed to the issue of the "Other" as the woman, we also need to have an idea of what the "Other Room" is. The "Other Room" literally means the bedroom, but in this case it is said to be the space where the woman is kept docile, oppressed, subjugated and exploited by the male folk. 
The "Other Room" in this context refers to the space where the woman is forced to inhabit. It is physical as well as psychological and also a strong symbolical representation of phallocentrism, which places the man on top of the woman as women are considered not to be a part of the ruling class of men. As such they have accepted their subordination for whatever reasons, hence display attitudes and conduct which are typically and traditionally ascribed as feminine (Janeway, 1971: 108). Since there is superiority of male power over women in the society, woman as "Other" is faced with all the validations that men have ever given, which were obviously prescribed by their own interest. So the woman does not argue for herself as subject because she does not have the wherewithal, and probably enjoys her role as the "Other" undoubtedly because of the ties that bind them together without taking for granted its mutuality. The Other room although not visible to the public space could indicate the inner or recess corner where the man proves his male virility, egoistic control and sometimes brawn or physical strength or power over the woman. It is indicative of the sexuality of the sexes and the woman is expected to comply whether or not she is sexually aroused when the man comes to meet her in the Other room. The sexual satisfaction of the man is assertive in the Other room and when not certified, the woman could take the blame and shamed in the outer space. The perception of the Other room as the woman's space is a symbolic relegation of the woman's dignity and a pointer to the fact that it has made women not seen and not heard.

Males and females co-exist in each society for the harmonious development and advancement of their nation; hence they share equal responsibilities in supporting their families but at the same time gender disparity causes a division among them even as a family. This division is not necessary because their goal is supposed to be for a united family front and the society at large. Even though the roles that women have to play are shaped in the image of women as "Others", not women as women, their own roles can become even strange to them; hence she surrenders herself as subordinate.

For her this Other appears in the essential mode, and she grasps herself as the inessential opposite him. She will free herself from her parents' home, from her mother's hold; she will open up her future not by an active conquest but by passively and docilely delivering herself into the hands of a new master. The destiny that society traditionally offers women is marriage... Marriage is the reference by which the single woman is defined (Beauvior, 1961: 502).

Marriage subjects the woman compulsorily to the "Other Room". Because being married allows the man to totally subjugate the woman as it defines who she is, even when it is not working. Most women have become "slaves" to their men instead of being a "partner", who provides strength and support to their home.

Being a woman in any patriarchal society is like being encircled in an evil sphere. So the woman completely resigns to what the society throws at her because she feels that she deserves being subdued. Simone de Beauvoir's argues that because men view women as fundamentally different from themselves, women are reduced to the status of the second sex and hence subordinate. However, if the woman is able to escape the patriarchal position in her family, she cannot run away from a patriarchal society. Hence, the subjugation of a woman after marriage and its attendant effects like motherhood, care-giving, and sex object, among others.

According to Sofola, to strip African females of essential sex-determined features is to "dewomanise" and rob her of her African identity (61) hence she remains in that subordinate position as a daughter, wife and mother, who establishes a divine equality with the man, which is apparently seen as a structured system of co-rulership (54). Motherhood and the care of the home, husband and family at large are the ultimate goals of a woman's life and her greatest creative opportunity; hence she allows the subjugation since she was never the one who chose her lot. This position of the woman consigns her to a sedentary existence since it is 'assumed' natural for her to stay at home and at the background. Chodorow, Ogunyemi, Kolawole and Oyewumi postulate within Western and African gender constructs that womanhood and especially motherhood is a central and defining feature of the social organization of gender that has continued to be considered central to the concerns of females. To them "the sanctity of motherhood meant that women were treated with respect" (Amadiume, 114) even when the construction and reproduction is constantly being negotiated to deprive it of bits and pieces of gendered oppression associated with patriarchy.

Therefore, this otherness and feeling of less self-worth that women feel is as a result of their separation from power in the society, not only in connection to men, but also in connection to themselves and their fellow women.

\section{Pan-Africanism as a tool for a way out of "the other room"}

Pan-Africanism has had a very profound impact on the national liberation struggle of the African people. As a movement of ideas and emotions, Pan-Africanism sometimes achieves a synthesis and at other times remains at the level of antithesis (Legum, 1962: 14) and a general movement of international kingship with a predominant cultural element (King, 1971; Weisbord, 1973), Pan-Africanism is a protest, a struggle, a refusal, a demand and a utopia by Africans and men of African blood born of centuries of contact with modern Europe (Langley, 1983; Thompson, 1969). Pan-Africanism is therefore a reaction against enslavement in whatever guise in Africa by nonAfricans and Africans alike. 
However, a fierce battle between the forces of reaction and progress is being fought around the concept so that it will not succeed. In order for Pan-Africanism to serve as a revolutionary ideology and movement, it must centre on the emancipatory needs of African women by way of a firm embrace of feminism. It would have to be an ideological stream of feminism that is opposed to imperialism, capitalism, racism, heterosexism/homophobia and other forms of oppression. Women are made invisible because the gender order has given men a more visible position, hence the decision to re-visibilize women. Rose Acholonu opines:

The tragedy of our underdevelopment, dehumanizing poverty, institutionalized and malignant sexism, as well as the degraded status of womanhood, have continued to bog down the life cycle of the average female, who whether as a daughter, sister, wife, mother or worker is often harassed or denied equal opportunities to enjoy the full benefits of her human rights (93).

In other words, women's liberation entails tackling gender injustice all the way from micro to the macro level, and not shying away from any level of struggle.

The most important purpose of Pan-Africanism as a way out of African patriarchal society is to examine the situation facing African women in every corner of the world, to solemnly protest the unjust contempt and odious treatment which are still heaped upon our women everywhere. Most of these women are compelled to remain silent so as to avoid being labeled unnatural, monstrous and even ostracized if she "rejects the submissive role patriarchy has reserved for her"(Toril Moi, 2002: 57). There are penalties of patriarchy, which is transferred and imbibed by future mothers from generation to generation as part of society's culture because of the identity assigned them as the "other" to men who have the right of existence because the women are parasites and hence have no independent existence.

Despite changes as an ideology and identity issue fashioned by its own success, Pan-Africanism still offers an appealing door to the past, serving as a political reference and even as an anchor to better set the demands of development that is based on a major regional integration.

\section{The potentials of the emancipated woman as an agent of development and societal change}

Emancipation implies formal, legal equality, put into place through legislation. Emancipation is a gateway through which liberation can be met, a positive and necessary tool in creating an equal society. Yesim Arat argues that the emancipated will begin to seek their own liberation by "challenging the boundaries that the state had drawn" (Arat, 2000, : 108); in other words, emancipation is an important and necessary step towards full liberation that represents progression. Emancipation dominates the public sphere because it is a tool used by the state, or demanded by individuals, to ensure legal rights, which is a formal type of equality although, it does not necessarily reflect a social attitude or value of equality. Emancipation, therefore, is a "political concern [to] equalize women to men in the public domain... the differences between men and women, especially in the private domain, were ignored" (Arat, 2000: 115).

Emancipation of women is possible when they are free to do things their way, get a world of their own to think freely, breathe in comfortably, and earn money to lead their lives without servile reliance on men because the accomplishment of human capability must be determined basically by freedom. Freedom is something more than maintaining one's existence in comfort and quietude; it elicits fulfillment. Emancipation is frequently used to reflect the condition of an independent society. Women's involvements in homes, workplaces and society at large are necessary for improving the society in general. We must, therefore, make empowerment a reality so that women can become the hero of their own emancipation.

Amy Ashwood Garvey averred that the emancipation of African women is a major part of her politics; she demonstrated her feminist and internationalist commitments: "There must be a revolution among women. They must realize their importance in the post-war world... Women of the world must unite" (1983). All societies need to encourage this process as part of our efforts to leave behind the archaic customs, sexist prejudices, and confinement to roles established for women by patriarchy. Focusing more support on girls offers an opportunity to replace that vicious cycle with a virtuous one that puts women at the centre of their families and their communities. As a result, women are able to bring in money to their families, get involved with local enterprises, and make sure their children are educated. These are vital agents of change. It is about giving women a choice. This newly-found female empowerment produces new behaviors, which in turn leads to extensive change.

Education is the medium by which a people are prepared for the creation of their own particular civilization and the advancement and glory of their own race. Receiving quality education therefore is more than a human rights issue, because an uneducated population has a direct effect on the labor market and country's ability to shift from an agrarian to industrial economy. Education is linked to demographic change by empowering women through their learning experience, and that empowerment leads to changed behaviors related to child-bearing and child-raising. Education builds strong societies, is a "widely accepted humanitarian obligation" and an internationally mandated human right (Cohen, Bloom, \& Malin, 2006). Education, the key to women's emancipation, must not only provide for skills development but must also instill from early childhood the values of love, equality and mutual respect. 
Education is essential to strengthening women's ability to participate in their countries' and their entire continent's development.

Until women and girls are liberated from poverty and injustice, all our goals - peace, security, sustainable development - stand in jeopardy. We must end inequality and discrimination and make women and girls aware of their inalienable rights. Women's contributions in homes and in work places are essential to improving the society. The task of the African womanist, therefore, is to give back to black women their own self, their strength, and their 'hoods' as in motherhood, sisterhood, wifehood, among others in terms of their deep spirituality, knowledge, overwhelming generosity, and selflessness to their family as well as the society in general. As posited by Muwati, Gambahaya, \& Gwekwerere (2011: 4):

Mother[hood] transcends being a mere biological designation to a philosophical and operational paradigm that ensures strategic intervention in crises while simultaneously serving as the community's strategic life-support resource.

This invariably infers that in Africa, the 'hoods' especially motherhood are not only seen as being exclusively complementary to fatherhood; rather, it "stands at the center of African life as a major organizing rubric around which life is constructed, sustained, and fulfilled” (Muwati, Gambahaya, \& Gwekwerere, 2011: 4). These 'hoods' are brought up as nurturers and homemakers, while at the same time taking care of other people and their environment.

A womanist as a woman is usually capable of displaying willful and extraordinarily determined behavior and lucidly articulating her political views in spite of the male efforts to prohibit her from any public discourse or even political dialogue. A womanist essential concern is the survival of the people with a focus on the non-separatist attitudes, which centers on wholeness of the entire people, male and female; hence they symbolically represent the collective struggle against the marginalization of African women at home and the Diaspora. These women stand for cultural identity, community and continuity (Nicholls, 2010: 30).

The women also need to be educated and made aware of the need to recover from psychological and mental traumas of inferiority, into which they have been consciously and unconsciously caged into. However, it becomes possible only if their wholeness and roundness as women are restored. Simon and Obeten state that the:

recognition of fundamental human rights of people-men and women, especially the black women who have suffered marginalization, oppression, deprivation etc, because of their sex" and recommends "that equal opportunities be given to women to showcase their talent, instead of being tied down with the tedium of life as wives, mothers, farm hands, punching bags, sex partners, hewers of wood and drawers of water (2013: 202).

The woman's strategy is basically focused on education as an effective means of bringing knowledge to the life of the oppressed and arming them with the political dexterity and understanding to fight against every oppressive system. The womanist views education from the point of indoctrination as well as a good means to enhance women's knowledge above the commonplace. The real mission of the womanist therefore is to indoctrinate the male child, so that women all over can emulate the method as a means to create a world void of patriarchy and its oppressive systems (Maleki \& Lalbakhsh, 2012: 74).

The womanist focuses on the unique experiences, struggles, needs, desires and strength of African women on ethics of survival. The womanist can no longer afford or tolerate any form of subjugation and aims to abolish disparate influences in their lives with the understanding that they can bring African men and women to the level of partners.

\section{Conclusion}

For African Pan-Africanism and Agenda 2063 aspirations and visions to be fully actualized, the traditional patriarchal outlook and approach of men towards women should be changed and women considered not as the "other" but rather as the friends of men and contributors to society. Women must be well educated with skills revolution underpinned by science, technology and innovation, allowing democratic values, practices, universal principles of human rights, justice and the rule of law to be ingrained, while capable institutions and transformative leadership should be put in place at all levels of the society. Women and girls should be allowed equal opportunity and participation in all spheres of life within the globe without any form of violence and discrimination, whether social, economic or political in the realization of collective African aims for a long-lasting, pleasant, all-encompassing prosperity.

This desire for liberation gives full meaning to, and is inspired by Pan-Africanism, especially because women are seen as the key agents and catalysts for positive social change and economic growth in all facets of African society.

Our vision is that we the African women will reclaim, reconstruct, and transform Africa, on the basis of gender equality, giving credence to the principles of democracy and human rights; mobilizing and utilizing human and other resources; and take our rightful place in the global arena, on the basis of equality with other nations, from now into the future, in 
partnership with our men, girls and boys (2015: 30).

Pan-Africanism further offers an appealing door to the past, serving as a political reference and an anchor to better set the demands of development that is based on a major regional integration aright by re-branding and restoring the lost glory and dignity of the African woman. Therefore, through capacity building and development, moral and religious teachings, cultural values and re-orientation as well as compulsory education, a woman as "other", is reconstructed and transformed from the "other room" to the centre stage of the society where she belongs.

Finally, Ogunyemi's African womanist vision of men and women working out their problems, and ultimately standing together (1985: 711), even when "sexism has diminished the power of all black liberation struggles - reformist or revolutionary" (hooks , 1990: 16) is still achievable because these women are mindful of their Africanness and the idiosyncrasies of that Africanness that make them distinct. African womanists favour the accommodative qualities and harmony between their men and women. Just like the Pan Africanist, they proffer solutions that are practical and will unite them, rather than expose oppressive tendencies that will cause them pains. These Pan-African womanists reconcile and support each other despite their differences instead of eradicating their differences in order to experience solidarity. They help articulate the togetherness, supportiveness, survival and wholeness of the entire African people, male and female; that in spite of their differences, they work as one to achieve a unified front against their oppressors. In the words of hooks,

Women do not need to eradicate difference to feel solidarity to end oppression. We do not need anti-male sentiments to bond us together, so great is the wealth of experience, culture, and ideas we have to share with one another. We can be sisters united by shared interests and beliefs, united in our appreciation for diversity, united in our struggle to end sexist oppression (1986: 127) 


\section{References}

Acholonu, C. (1995). Motherism: The Afrocentric Alternative to Feminism. Owerri: Afa Publications.

Adágbádá, O. (2015). Traditional and Contemporary Ethnic Dispositions to Women as Leaders in Yorùbá Films, International Journal of Humanities Social Sciences and Education (IJHSSE) January 2(1): 72-82

Adi, H. \& Sherwood, M. (2003). Pan-African history: Political Figures from Africa and the Diaspora since 1787. London: Routledge.

Aidoo, A. A. (1984). To Be A Woman. Robin Morgan, (ed.), Sisterhood is Global Garden City NY: Anchor/Doubleday.

------ (1993). Male-ing Names in the Sun, Shirley Chew \& Anna Rutherford, (eds.) Unbecoming Daughters of the Empire. Dangaroo Press.

------- (1998). The African Woman Today, Obioma Nnaemeka, (ed.), Sisterhood, Feminisms and Power. From Africa To The Diaspora Trenton, N.J. 249 \& Asmara: Africa World Press. 30-50

Adogamhe, P. (2008). Pan-Africanism Revisited: Vision and Reality of African Unity and Development. African Review of Integration 2(2):1-34.

Agyeman, O. (1975). The Osagyefo, The Mwalimu, and Pan-Africanism: A Study in the Growth of a Dynamic Concept,. The Journal of Modern African Studies 13(4):653-675.

Alexander, N. (2003). New Meanings of Pan-Africanism in the Era of Globalisation. In The Fourth Annual Frantz Fanon Distinguished Lecture, 8 October, Chicago: DePaul University.

Amadiume, I. (1987). Male Daughters, Female Husbands: Gender and Sex in an African Society. London: Zed Books.

Ampofo, A. A., J. Beoku-Betts \& M. J. Osirim (2008). Researching African Women and Gender Studies: New Social Science Perspectives. African and Asian Studies, 7: 327-341.

Arat, Y. (2000). From Emancipation to Liberation: The Changing Role of Women in Turkey's Public Realm Journal of International Affairs, 54(1), pp. 107-123.

Awe, B. (2000). Ed. Nigerian Women in Historical Perspectives, Lagos: Sankore Book craft.

Azikiwe, A. (2016). Pan-Africanism, women's emancipation and the meaning of socialist development Sep 08, https://www.genderminorities/pan-africanism-women\%E2\%80\%99s-emancipation-andmeaningsocialist-development

Azikiwe, N. (1962). The Future of Pan-Africanism Présence Africaine, English Edition, Vol. 12, No. 40, First Quarterly.

Azodo, A. (2007). Facing the Millenium: An Interview with Ama Ata Aidoo. Azodo and Wilentz, (eds.), 429-41. Azodo, Ada and Eke, Maureen, (eds.) Gender and Sexuality in Africa Literature and Film. Trenton, NJ: Africa World Press.

Barrow, R. \& Geoffery, M. (1990). A Critical Dictionary of Education Concepts. 2nd edition. New York: Harvester Wheatsheaf.

Beasley, C. (1999). What is Feminism: An Introduction to Feminist Theory. London: Sage Publications. Bhasin, K. (2006). What Is Patriarchy. Women Unlimited: New Delhi.

Biney, A. (2011). The Political and Social Thought of Kwame Nkrumah. New York: Palgrave MacMillan Press.

Biney, A. (2008). The Legacy of Kwame Nkrumah in Retrospect. The Journal of Pan African Studies 2 (3):129-159.

Bogues, A. (2011). C.L.R. James, Pan-Africanism and the Black Radical Tradition Critical Arts: South-North Cultural and Media Studies, 25:4, 484-499

Brown-Douglas, K. (1993). The Black Christ. Maryknoll, NY: Orbis Books.

Bryant-Davis, T. \& Comas-Díaz, L. (2016). Introduction: Womanist and Mujerista Psychologies American Psychological Association 1-25 http://dx.doi.org/10.1037/14937-001

Campbell, H. (1994). Pan Africanism and African Liberation, Lemelle, Sydney J. and Kelley, Robin G. (eds.) Imagining Home: Class, Culture and Nationalism in the African Diaspora. London and New York: Verso.

Christian, B. (1985). Alternative Versions of the Gendered Past: African Women Writers vs Illich. Black Feminist Criticism. New York: Pergamon Press. 
Chukwuma, H. (2000). The Identity of Self. Introduction. Feminism in African Literature: Essays on Criticism. Enugu: New Generation Books, 1994: ix.

- (2000). The face of Eve: Feminist writing in African Literature. Opata, D.U. and Ohaegbu, A.U. (eds.) Major Themes in African Literature. Nsukka: A.P. Express Publishers, 101 144.

Clifford, M. A. (2001). Introducing Feminist Theology. Maryknoll: New York.

Cohen, J. E., Bloom, D. E., \& Malin, M. B. (2006). Educating All Children: A Global Agenda. Cambridge, MA: The MIT Press.

Corneliussen, E. (2012). Breaking the Silence: The influence of Class, Culture and Colonisation on African Women's Fight for Emancipation and Equality in Tsitsi Dangarembga's Nervous Conditions and Chimamanda Adichie's Purple Hibiscus Master's Thesis in English Literature Faculty of Humanities, Social Sciences and Education University of Tromsø, $1-81$.

de Beauvoir, S. (1949/1961/1986). The Second Sex. Trans. and ed. by H. M. Parshley, London: Four Square Books Limited.

Dove, N. (1998). African Womanism: An Afrocentric Theory. Journal of Black Studies, 28(5): 515539.

Echo, A.U. (2013). Pan-Africanism and African Renaissance. In M. W. Makgoba (ed) African Renaissance, Issue 05, January 27, South Africa: Mafube, Sandton.

Elias, M. (2010). Transforming Nature's Subsidy: Global Markets, Burkinabe Women and African Shea Butter. McGill University. Retrieved from http://www.collectionscanada.gc.ca/obj/thesescanada/vol2/QMM/TC-QMM-94971.pdf.

Esedebe, P. O. (1984). Pan-Africanism: The Idea and Movement, 1976-1991, Washington D.C.: Howard University Press.

Falola, T. (1991). Yoruba Histriography. Madison: University of Wisconsin African Studies Programme.

Fanon, F. (1963). Black Skin, White Masks. Harmondsworth: Penguin.

FEMNENT, (2015). Pan-African Organizing for a Collective Approach to Agenda 2063. In Year of Women's Empowerment and Development Towards Africa's Agenda 2063. The Newsletter of the AU Commission, Issue 1, pp. 28-31.

Francis, D. J. (2006). Uniting Africa: Building Regional Peace and Security Systems. Burlington, VT: Ashgate Publishing Company.

Friedan, B.(1963). The Feminine Mystique. New York: Norton.

Gabriel, D. (2007). Sisters in the Struggle: Celebrating African Female Resistance to Slavery, Colonisation and the Legacies of Chattel Enslavement Black Britain 1-6 http://www.colourfulnetwork.net/print/?i=98\&c=Featu re\&n=bbo\&a=print

Gamble, S. (2001). The Routledge Companion to Feminism and Postfeminism. New York, NY: Routledge.

Garvey, A. A. (1983). The Birth of the Universal Negro Improvement Association, in Martin, Tony The Pan African Connection: From Slavery to Garvey and Beyond. Dover, Mass: The Majority Press.

Gramsci, A. (1971/ 2004). Selections from the Prison Notebooks of Antonio Gramsci. Trans. \& ed. Quintin Hoare \& Geoffrey Nowell Smith. Chennai: Orient Longman.

Harrell, S., Coleman, A., \& Adams, T. (2014). Toward a Positive Womanist Psychospirituality: Strengths, Gifts, and Optimal Well-being among Women of African Descent. In T. Bryant-Davis, A. Austria, D. Kawahara, \& D. Willis (Eds.), Religion and Spirituality for Diverse Women: Foundations of Strength and Resilience (pp. 49-70). Santa Barbara, CA: Praeger.

Hartmann, S. M. (1989). From Margin to Mainstream: American Women and Politics since 1960 Philadelphia: Temple University Press.

hooks, b. (1998). Black Feminism: Historical Perspective. Liggings Hills et al (eds.) Call and Response: The Riverside Anthology of African American Literary Tradition. Boston: Hughton Mifflin Company.

------- (2008). Belonging: A Place of Culture. New York: Routledge

Hudson-Weems, C. (1994). Africana Womanism. Troy, Michigan: Bedford Publishers

Janeway, E. (1971). Man's World, Woman's Place - A study in Social Mythology, New York: William Morrow And Company, Inc. 
Jones, S. (2000). Feminist Theory and Christian Theology: Cartographies of Grace. Minneapolis: Fortress press

Kanu, I. A. (2013) Nkrumah and the Quest for African Unity American International Journal of Contemporary Research June 3(6): 111-114

Khumalo-Sakutukwa, G. and Garbus, L. (2002). HIV/AIDS in Zimbabwe. San Francisco: University of California.

King, K.(1971). Pan-Africanism and Education. London: Oxford University Press.

Kobo, F. (2016). "Umfazi akangeni ebuhlanti emzini... A Womanist Dialogue with Black Theology of Liberation in the 21st Century" Herv. teol. stud. vol.72 n.1 Pretoria http://dx.doi.org/10.4102/hts.v72i1.3268

Kolawole, M.M. (1997). Womanism and African Consciousness. New York: Africa World Press.

Langley, J. A. (1973). Pan-Africanism and Nationalism in West Africa, 1900 - 1945. London: Oxford University Press.

Legume, C. (1972). Pan-Africanism and Nationalism. Africa in the Nineteenth and Twentieth Centuries. Ed. J.C Anene and G. Brown. Ibadan: Ibadan University Press; 528 - 538.

Lemelle, S. (1992). Pan Africanism for Beginners. London: Writers and Readers.

Lerner, G. (1989). The Creation of Patriarchy. Oxford University Press: New York.

Lippa, R. (2002). Gender, Nature, and Nurture. New Jersey: Lawrence Erlbaum Associates.

Lloyd, B. (1981). Women Writers in Africa. USA: Greenwood Press.

Madunagu, B. E. (2008). The Nigerian Feminist Movement: Lessons from "Women in Nigeria, WIN Review of African Political Economy Public/Private, Global/Local: The Changing Contours of Africa's Security Governance Dec. 35(118): 666-672

Maleki, N., \& Lalbakhsh, P. (2012). Black Woman, Indoctrination of The Male, And Subversion of the Patriarchy in Ngugi's Weep Not, Child. The Southeast Asian Journal of English Language Studies, 18(4), $65-74$

Mama, A. (2016). Feminism: Africa And African Diaspora New Dictionary of the History of Ideas https://encyclopedia.com

Mazrui, A. (2004). Nkrumah's Legacy and Africa's Triple Heritage Between Globalization and Counter Terrorism. Accra: University Press.

Mohanty T. C. (2003). Feminism without Borders: Decolonizing Theory, Practicing Solidarity. Durham and London: Duke University Press.

Moi, T. (2002). Sexual/Textual Politics, Feminist Literary Theory, 2nd Edn London and New York: Routledge Taylor \& Francis Group.

Mudimbe, V.Y. (1994). The idea of Africa. Indianapolis: Indiana University Press.

Murithi, T. (2007). Between Paternalism and Hybrid Partnership: The Emerging UN and Africa Relationship in Peace Operations. Friedrich Ebert Stiftung Briefing Paper. New York: FES.

- (2005). The African Union: Pan-Africanism, Peacebuilding and Development. Aldershot: Ashgate.

Muwati, I. \& Gambahaya, Z. \& Gwekwerere, T. (2011). "African Womanism and African Proverbs: Theoretical Grounding of Mothering/Motherhood in Shona and Ndebele Cultural Discourse." Western Journal of Black Studies, 35 (1), 1-8.

Nicholls, B. (2012). Ngugi wa Thiong'o, Gender, and the Ethics of Postcolonial Reading. Burlington: Ashgate Publishing Company.

Nkrumah, K. (1963). African Must Unite. London: Panaf

Nwoko, M. (2006). Basic World Political Theories. F. O. C Njoku (Ed.). Enugu: Snaap

Ogba, A. S. \& Okpanachi, I. A. (2014). "Decolonization in Africa and Pan-Africanism”. Yönetim Bilimleri Dergisi 12(23): 7-31

Ogundipe-Leslie M. (1994). Re-Creating Ourselves.African Women and Critical Transformation. New York: Africa World Press.

Okeke, V.O.S \& Okechukwu, E. (2011). Pan-Africanism and Pan-Arabism in Africa: The Thesis, the Anti-thesis and Imperative for Synthesis Kuwait Chapter of Arabian Journal of Business and Management Review September 1(1): 87-106

Okhonmina, S. (2009). "The African Union: Pan-Africanist Aspirations and the Challenge of African Unity”. The Journal of Pan African Studies 3(4):85-100. 
Okonjo-Ogunyemi, C. (1983). Womanism: The Dynamics of the Contemporary Black Female Novel in English. Signs. Vol. 11. No 1. Autumn; $63-80$.

Olaosebikan, J. (2011). Kwame Nkrumah and the Proposed African Common Government. African Journal of Political Science and International Relations 5(4): 218-228.

O'Meally, S. (2013). "Is it Time for a New Paradigm for 'Citizen Engagement'? The Role of Context and What the Evidence Tells Us”. Retrieved 29 February 2017, from World Bank Blogs on People, Spaces, Deliberation: https://blogs.worldbank.org/publicsphere/ it-time-newparadigm-citizen-engagement-role-context-and-whatevidence-tells-us

Oyewunmi, O. (1997). The Invention of Women: Making an African Sense of Western Gender Discourse Minneapolis: University of Minnesota Press.

------- (1995). Colonizing Body and Mind. The Post-Colonial Studies Reader. Routledge.

Quist-Adade, C. (2010). Welcome Address at Opening Ceremony of Kwame Nkrumah International (KNIC) Conference held at Richmond, British Columbia, Canada, on 19 August, the Patriotic Vanguard, 24 August.

Reddock, R. (2014). The first Mrs Garvey: Pan-Africanism and feminism in the early 20th century British colonial Caribbean Feminist Africa 19: 58-77 https://www.researchgate.net/ publication $/ 273003421$

Rich, A. (1976). Of Woman Born: Motherhood as Experience and Institution. New York: W. W. Norton.

Rublin, A. D. (2007). Though all Women are Women, no Woman is only a Woman: Black, White, and Chicana Feminist Consciousness Development from 1955 to 1985 Honors Program in History (Senior Honors Theses). 5. http://repository.upenn.edu/hist_honors/5 i-115

Saaka, Y. (1994). Recurrent Themes in Ghanaian Politics: Kwame Nkrumah's Legacy. Journal of Black Studies 24 (3): 263-280: Special Issue: Social, Economic, Political, and Cultural Dimensions of Life in Ghana.

Salami, M. (2018). Feminism in Nigeria - By and for who? Afrika, Feminismus September. Zeitschrift LuXemburg - Gesellschaftsanalyse und linke Praxis.

Shema-Rutagengwa. (2009). Pan-Africanism Through Peace, Nonviolence and a Nondiscrominative Lens Feb. 9 Transcend Media Service Solutions-Oriented Peace Journalism https://www.transcend.org/tms/author /?a=Claude\%20Shema-Rutagengwa,\%20M.D.

Simon, E.D., \& Obeten, M.I. (2013). Impact of Pan-Africanism on African Feminism: A Study of Buchi Emecheta's Destination Biafra. International Journal of Humanities and Social Science, 3 (8), 202-08.

Singh, S. (1997). Feminism: theory criticism analysis. New Delhi: Rencraft International.

Sofola, Z. (1998). Feminism and African Womanhood. Nnaemeka O. (ed.) Sisterhood: Feminisms and Power from Africa to the Diaspora, Trenton, NJ: Africa World Press. 51-64.

Sotunsa, M. (2008). Feminism and Gender Discourse. Sagamu: Ojoko-BiriKale Press.

Spelman, E. V. (1988). Inessential Woman: Problems of Exclusion in Feminist Thought Boston: Beacon Press.

Spivak, G.C. (1988). Can the Subaltern Speak? In Nelson, C. \& Grossberg, L. (eds.). Marxism and the Interpretation of Culture. Urbana/Chicago: University of Illinois Press, pp. 271-313.

------- (1987). A Literary Representation of the Subaltern: A Woman's Text from the Third World. In Other Worlds: Essays in Cultural Politics. New York: Methuen. $241-268$.

------- (1987). French Feminism in an International Frame. In Other Worlds: Essays in Cultural Politics. New York: Methuen. 134 - 153.

Strong-Leek, L. (2005). Emerging Womanism in the Works of Tsitsi Dangaremba, Barbara Mahkalisa and J. Nozipo Makraire Edris Makward, Mark L. Lilleleht, \& Ahmed Saber (eds.) North-south Linkages and Connections in Continental and Diaspora African Literatures. Trenton, Asmara: Africa World Press.

Sultana, A. (2010/2011). Patriarchy and Women's Subordination: A Theoretical Analysis The Arts Faculty Journal, July - June; 1-15

Therborn, G. (2004). Between Sex and Power-Family in the World, 1900-2000. John Urry (ed), London \& New York: Routledge.

Thompson, V. B. (1969). Africa and Unity: The Evolution of Pan-Africanism. London: Longman. Tong, R. (1989). Feminist Thought: A Comprehensive Introduction. Colorado, Westview Press. 
Tsikata, D. (2001). The Politics of Policy Making: A Gender Perspective, D. Tsikata (ed.), Gender Training in Ghana: Politics, Issues and Tools. ISSER/DAWS/ TWN Accra: World Publishing Services.

Tuttle, L. (1986). Encyclopedia of Feminism. New York: Facts on file Publication.

Walby, S. (1990). Theorizing Patrirachy. Oxford: Blackwell.

Walker, A. (1983). In Search of Our Mothers' Gardens: Womanist Prose. New York: Harcourt Brace Jovanovich.

Weisbord, R. G. Ebony Kinship: Africa, Africans, and the Afro-American. Westport, Conn.: Greenwood Press.

Westfield, N. L. (2007). Dear Sisters: A Womanist Practice of Hospitality. Bohemia, NY: Pilgrim Press. Williams, M. (2005). The Pan-African Movement. Mario Azevedo (ed.) Africana Studies: A Survey of Africa and the African Diaspora. Carolina Academic Press.

Wolfreys, J. (2004). Critical Keywords in Literary and Cultural Theory. New York: Macmillan. 